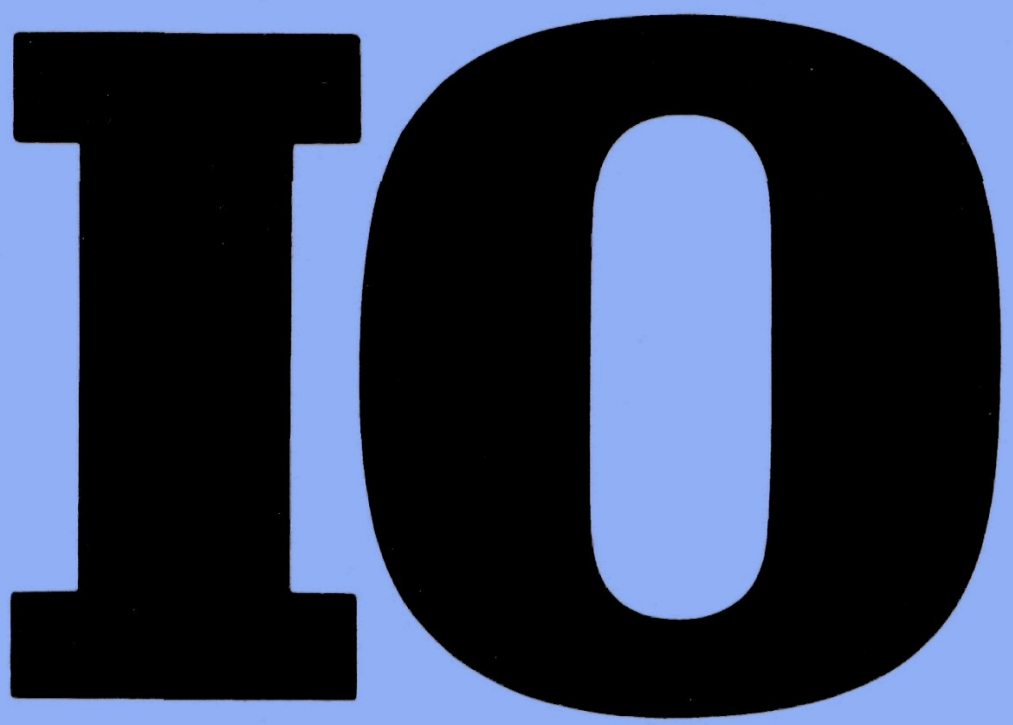

\title{
Intermational Osganivation
}

John E. Richards

Regulating International Aviation Markets

J. Lawrence Broz

Origins of the Federal Reserve System

William Bernhard and David Leblang

Democratic Institutions and Exchange-rate Commitments James E. Alt, Fredrik Carisen, Per Heum, and Kåre Johansen

Asset Specificity and the Political Behavior of Firms

Kishore Gawande and Wendy L. Hansen

Retaliation, Bargaining, and the Pursuit of "Free and Fair" Trade Timothy J. McKeown

Case Studies and the Statistical Worldview 
Edited at the University of California, San Diego

Published quarterly by The MIT Press

Founded in 1947 by the World Peace Foundation

Robert Bates
Benjamin J. Cohen
Matthew Evangelista
James Fearon
Martha Finnemore
Jeff Frieden
Geoffrey Garrett
Judith Goldstein
Peter Gourevitch
Christer Jönsson
Miles Kahler
Peter Katzenstein
Robert O. Keohane
David A. Lake
Charles Lipson
Lisa Martin

\section{Peter Gourevitch Editors \\ David A. Lake}

Stephan Haggard

Jack Snyder

Lynne L. Bush

Janice Stein Editorial Board Chair

Helen V. Milner

Editorial Board

Review Editors

Managing Editor

John Odell

Louis Pauly

Robert Powell

J. David Richardson

Thomas Risse

Volker Rittberger

Ronald Rogowski

Frances Rosenbluth

Kathryn Sikkink

Beth Simmons

Anne-Marie Slaughter

Arthur Stein

Janice Stein

Beth V. Yarbrough

Mark W. Zacher

INTERNATIONAL ORGANIZATION invites the submission of original manuscripts on all aspects of world politics and international political economy. Authors should follow the guidelines published annually in the Winter issue. Guidelines also may be found on the World Wide Web at http://mitpress.mit.edu/IO.

Address for submissions:

Lynne Bush

Managing Editor

International Organization

IR/PS

University of California, San Diego

9500 Gilman Drive

La Jolla, CA 92093-0519

Statements and opinions expressed in International Organization are the responsibility of the authors alone and do not imply the endorsement of the Board of Editors, the Board of Trustees of the World Peace Foundation, the University of California, or The MIT Press.

For abstracting listing and price information, please refer to the back of this issue.

Periodicals postage is paid at Boston, Mass., and at additional mailing offices.

1999 by The IO Foundation and the Massachusetts Institute of Technology ISSN 0020-8183

$@$ This publication is printed on acid-free paper. 


\section{International Organization}

Volume 53, Number 1, Winter 1999

\section{Articles}

Toward a Positive Theory of International Institutions: Regulating International Aviation Markets John E. Richards

Origins of the Federal Reserve System: International Incentives and

the Domestic Free-rider Problem J. Lawrence Broz

Democratic Institutions and Exchange-rate Commitments

William Bernhard and David Leblang

Asset Specificity and the Political Behavior of Firms: Lobbying for

Subsidies in Norway James E. Alt, Fredrik Carlsen, Per Heum, and Kåre Johansen

Retaliation, Bargaining, and the Pursuit of "Free and Fair" Trade

Kishore Gawande and Wendy L. Hansen

\section{Review Essay}

Case Studies and the Statistical Worldview: Review of King,

Keohane, and Verba's Designing Social Inquiry:

Scientific Inference in Quantitative Research

Timothy J. McKeown

Guidelines for Contributors 


\section{Contributors}

James E. Alt is Professor of Government and Director of the Center for Basic Research in Social Science at Harvard University, Cambridge, Massachusetts. He can be reached at james_alt@harvard.edu.

William Bernhard is Assistant Professor of Political Science at the University of Illinois at Urbana-Champaign. He can be reached at bernhard@uiuc.edu.

J. Lawrence Broz is Associate Professor of Government at Harvard University and Faculty Associate at the Weatherhead Center for International Affairs at Harvard University. He can be reached at lbroz@cfia.harvard.edu.

Fredrik Carlsen is Associate Professor of Economics at the Norwegian University of Science and Technology, Trondheim, Norway. He can be reached at fredrik.carlsen@sv.ntnu.no.

Kishore Gawande is Associate Professor of Economics at the University of New Mexico, Albuquerque, New Mexico. He can be reached at gawande@unm.edu.

Wendy Hansen is Associate Professor of Political Science at the University of New Mexico, Albuquerque, New Mexico. She can be reached at wlhansen@unm.edu.

Per Heum is Director of the Center for Research in Economics and Business Administration, Bergen-Sandviken, Norway. He can be reached at per.heum@snf.no.

Kåre Johansen is Associate Professor of Economics at the Norwegian University of Science and Technology, Trondheim, Norway. He can be reached at kare.johansen@sv.ntnu.no.

David Leblang is Assistant Professor of Political Science at the University of North Texas, Denton, Texas. He can be reached at dleblang@unt.edu. 
Timothy J. McKeown is Associate Professor of Political Science at the University of North Carolina, Chapel Hill. He can be reached at tim_mckeown@unc.edu.

John E. Richards is Director of the International Computer Services Research at the Stanford Computer Industry Project, Stanford, California. He can be reached at John.Richards@stanford.edu. 


\section{Abstracts}

\section{Toward a Positive Theory of International Institutions: Regulating International Aviation Markets}

by John E. Richards

The regulation of postwar international aviation markets suggests that existing approaches to international institutions cannot adequately account for important elements of international institution building. In particular, scholars have neglected how domestic politics shapes the incentives of national governments to create and maintain international institutions and the impact of domestic politics on the scope and functions of international institutions. Drawing on positive theories of regulation and the literature on property rights, I argue that national politicians use international institutions to increase the wealth available for domestic redistribution. In short, national politicians create and maintain international institutions to maximize domestic political support. I present a domestic political model that explains how, when, and why national politicians create international institutions. The model is applied to the creation of institutions governing international aviation markets in the late $1940 \mathrm{~s}$ and the reformulation of these institutions over the past two decades.

\section{Origins of the Federal Reserve System: International Incentives and the Domestic Free-rider Problem}

by J. Lawrence Broz

The Federal Reserve System was established in 1913 to provide the public good of domestic financial system stability. Its main purpose was to safeguard the nation from banking panics and other economically costly financial disturbances. In this article, I explain the collective action behind the Federal Reserve Act by way of the joint products (selective incentives) model. The selective inducement that motivated lobbying for the Federal Reserve was the desire to internationalize usage of the U.S. dollar, a benefit restricted primarily to moneycenter bankers. Bankers internalized the costs of producing the Federal Reserve because the private gains associated with internationalizing the currency could not be disassociated from production of domestic financial stability. The article provides a road map of the joint products model and demonstrates empirically the supply technology that bound together the public and private goods of the Federal Reserve Act. 


\section{Democratic Institutions and Exchange-rate Commitments}

by William Bernhard and David Leblang

Since the collapse of the Bretton Woods system, countries have been able to choose from a variety of exchange-rate arrangements. We argue that politicians' incentives condition the choice of an exchange-rate arrangement. These incentives reflect the configuration of domestic political institutions, particularly electoral and legislative institutions. In systems where the cost of electoral defeat is high and electoral timing is exogenous, politicians will be less willing to forgo their discretion over monetary policy with a fixed exchange rate. In systems where the costs of electoral defeat are low and electoral timing is endogenous, politicians are more likely to adopt a fixed exchange-rate regime. Consequently, differences in domestic political systems can help account for variations in the choice of exchange-rate arrangements. We test this argument using constrained multinomial logit and binomial logit on a sample of twenty democracies over the period 1974-95. Domestic political institutions have a significant effect on exchange-rate regime choice, even after controlling for systemic, macroeconomic, and other political variables.

\section{Asset Specificity and the Political Behavior of Firms: Lobbying for Subsidies in Norway \\ by James E. Alt, Fredrik Carlsen, Per Heum, and Kåre Johansen}

Previous research into endogenous trade policy has described extensively the political incentives of firms with specific assets, but no studies have shown directly that firms behave as predicted. We adopt insights from transaction costs economics to develop measures of asset specificity and to investigate how variation in these measures affects the political behavior of firms. In particular, we examine the lobbying choices of Norwegian firms in the 1980s. Given available subsidy funds from Norway's oil boom and some government decisions in the 1970s, firms with more specific assets faced potentially greater losses from adjusting to new activities in the face of competitive pressures and thus had greater incentives to lobby for subsidies to protect themselves. Joint contacting of Parliament and government on behalf of firm interests by representatives of both management and labor should be particularly likely where firms had specific assets. Data analysis shows that asset specificity, as indicated by R\&D intensity and job immobility, predicts joint contacting independently of plausible alternative explanatory variables like firm size and export orientation.

\section{Retaliation, Bargaining, and the Pursuit of "Free and Fair" Trade by Kishore Gawande and Wendy L. Hansen}

That domestic political economic factors are important determinants of a nation's trade barriers has been empirically well established. However, the question of how effective strategically retaliatory trade barriers are in deterring foreign protectionism has received far less systematic empirical attention. In this article we use bilateral nontariff barrier (NTB) data between the United States and five developed partner countries (Japan, France, Germany, Italy, and the United Kingdom) to systematically examine the effectiveness of strategic retaliation. We employ a simultaneous Tobit model where the home and foreign NTB levels are determined endogenously in a bilateral game. The model provides estimates of deterrence coefficients, that is, the reduction in foreign trade barriers as a result of U.S. retaliation, which we use to characterize the nature of bilateral NTB games. Our hope is that the empirical results presented here, which have realistic though controversial implications, will inform U.S. trade policy. 
Case Studies and the Statistical Worldview: Review of King, Keohane, and Verba's Designing Social Inquiry: Scientific Inference in Qualitative Research. by Timothy J. McKeown

Gary King, Robert O. Keohane, and Sydney Verba's Designing Social Inquiry exploits the metaphor of researcher-as-statistician to develop guidelines for conducting social scientific research that are allegedly applicable to all empirical investigations. Their approach has sharp and often unflattering implications for case studies and similar research strategies. Because their statistical worldview is unable to make sense of important aspects of case study research or of the importance that is sometimes attached to the findings of a single case, their argument seemingly casts doubt on the wisdom of producing or consuming such studies.

I argue that the foundation of classical statistics and the epistemology of Carl Hempel and Karl Popper is an inadequate and misleading basis for a critical evaluation of case studies. I then present examples of research that are not easily accommodated within the authors' framework and sketch the elements of an alternative epistemological framework rooted in a "pattern" model of explanation. The latter is a standpoint that is much more helpful in understanding and criticizing case studies than the framework presented in Designing Social Inquiry. 